\title{
Quality characteristics of ground coffee extracts according to physical and chemical defects
}

\author{
Jun-Hyung Sung ${ }^{1}$, Jeong-Seok Cho ${ }^{1}$, Hyeon-Jeong Lee ${ }^{1}, \mathrm{Ji}^{-}$Young Choi ${ }^{1}$, \\ Yeong-Min Lee ${ }^{1}$, Luo Jin ${ }^{1}$, Kwang-Deog Moon ${ }^{1,2 *}$ \\ ${ }^{1}$ Department of Food Science and Technology, Kyungpook National University, Daegu 41566 Korea \\ ${ }^{2}$ Food and Bio-Industry Research Institue, Kyungpook National University, Daegu 41566, Korea
}

\section{커피빈의 물리화학적 결점에 따른 추출액의 품질특성}

\author{
성준형 $^{1} \cdot$ 조정석 ${ }^{1} \cdot$ 이현정 ${ }^{1} \cdot$ 최지영 ${ }^{1} \cdot$ 이영민 $^{1} \cdot$ 루오진 $^{1} \cdot$ 문광덕 $^{1,2 *}$ \\ ${ }^{1}$ 경북대학교 식품공학부, ${ }^{2}$ 경북대학교 식품생물산업연구소
}

\begin{abstract}
To examine the utilization possibility of defective coffee beans, non-defective and defective coffee bean were compared by means of its physiochemical properties and antioxidant capacities measured by DPPH radical scavenging activity, FRAP assay, total phenol contents, functional component (trigonelline, caffeine, chlorogenic acid) contents. After roasting process, $\mathrm{pH}$ and soluble solid contents of coffee extracts decreased; $\mathrm{L}^{*}$ value decreased while $\mathrm{a}^{*}$ and $b^{*}$ values increased. DPPH radical scavenging activities of defective green bean extracts were higher than that of non-defective green bean extracts. Immature green bean extract showed the highest radical scavenging activity. In FRAP assay, green bean extracts ranged from 15.28 21.80 $\mathrm{mM}$ TE which was higher than roasted bean extracts which showed 14.81 16.38 mM TE. Total phenol contents of green bean extracts ranged 191.06 256.25 mg\% GAE which was higher than that of roasted bean extracts showed 161.91 173.44 mg\% GAE. The contents of trigonelline, caffeine, chlorogenic acid in immature green bean extract were the highest, which showed $895.20 \mathrm{mg} / \mathrm{L}$, $825.85 \mathrm{mg} / \mathrm{L}$ and $3,836.94 \mathrm{mg} / \mathrm{L}$ respectively. Each contents were decreased after roasting process. Results of this study suggest that defective coffee bean can be used as a functional food material.
\end{abstract}

Key words : defective coffee bean, physicochemical properties, functional properties, antioxidant capacities, immature bean

\section{서 론}

커피는 세계 물동량의 2위를 차지하며 세계적으로 하루 약 5천 만잔 이상이 소비되는 대중적인 음료이다(1). 커피나 무는 에티오피아가 원산지이며 현재 아프리카, 남아메리 카, 베트남, 인도네시아 등지에서 널리 재배되고 있다(2). 커피는 인류가 가장 많이 마시는 기호음료로 식물 중 가장

*Corresponding author. E-mail : kdmoon@knu.ac.kr Phone : 82-53-950-5773, Fax : 82-53-950-6772

Received 1 February 2016; Revised 5 July 2016; Accepted 29 July 2016.

Copyright (c) The Korean Society of Food Preservation. All rights reserved.
풍부한 휘발성 향기성분을 함유하고 있으며, 지금까지 확 인된 커피의 향기성분은 800 가지 정도이며 비극성 물질에 서 극성 물질까지 폭넓게 분포하고 있다 $(3,4)$. 커피의 섭취 는 각성효과 및 기분전환 등의 정신적인 효과(5)가 있으며, 커피의 항산화효과에 대한 연구로 다양한 음료에서 페놀화 합물의 함량을 측정한 결과 레드와인보다 커피의 페놀함량 이 높은 것으로 나타났다(6). 생리적인 효과에 대한 연구도 진행되었는데 췌장염의 위험을 감소시킨다는 보고(7), 당 뇨의 발병을 낮춘다는 보고(8)가 있었다. 또한 알츠하이머 나 파킨슨병 등의 신경학적 질환과 산화적 스트레스로 인한 대사성 질환의 위험을 감소시키는 것으로 보고되었다(9). 이러한 커피의 품질에 영향을 미치는 여러 가지 요소 중에 서 Farah A등(10) 의 연구에서는 결점두 함량은 그 양이 
많이 발견된 생두일수록 향미에 부정적인 영향을 미친다고 보고하였다. 결점두란 생두 중에서 결함이 있는 것으로 로 스팅 후 커피의 맛과 향 등의 품질에 악영향을 미칠 수 있는 것들을 지칭한다(11). 결점두의 종류로는 black, sour, broken과 같이 가공 시 생성되는 것과 돌, 나뭇가지 등과 같은 외부물질이 유입되는 경우가 있다(12). Immature bean 은 주로 미숙한 과실에서 유래되며 떫은맛을 증가시키는 것으로 알려져 있다(13). Sour bean은 노르스름한 갈색을 띤 발효된 콩으로 성장기간 중 물의 결핍이나 비정상적인 발효에 의해 발생하며 식초같은 시큼한 냄새을 낸다(14). Broken bean은 깨진 생두로써 로스팅 과정 시 골고루 열이 전달되지 않아 전체적인 향미에 부정적인 영향을 미친다고 보고되었다(15). 현재 커피의 성분분석에 관한 연구로는 커피의 종류에 따른 이화학적 성분 및 $\mathrm{GC}$ 에 의한 향기성분 분석(16), 로스팅 및 추출조건에 따른 품질분석(17), 커피의 추출방법에 따른 이화학적 특성(18) 등 많은 연구가 보고된 바 있으나 결점두에 대한 연구는 아직 미흡한 실정이다. 따라서 본 연구에서는 정상두와 결점두의 생두와 로스팅 후 이화학적 특성, 항산화능, HPLC를 통한 trigonelline, caffeine, chlorogenic acid의 기능 성분 분석을 통하여 로스 팅 유무에 따른 정상두와 결점두의 차이를 알아보고 결점두 의 활용가능성을 검토하고자 하였다.

\section{재료 및 방법}

\section{실험 재료}

본 실험에 사용한 커피빈은 에티오피아에서 생산된 시다 모 G4 등급을 (주)우성엠에프(Seoul, Korea)에서 구입하여 사용하였다. 시다모 G4 등급은 Arabica 품종이며, 커피빈은 미국 스페셜티 커피협회(SCAA, Specialty coffee Association of America)의 기준에 의하여 정상두와 결점두(Immature, Fungus, Broken, Sour)로 분류하였다. Immature는 익지 않은 상태에서 수확한 것으로 은피가 단단히 붙어있으며 크기가 작고 오목하며, Fungus는 곰팡이에 의해 푸른색을 띠며, Broken은 가공 시 깨진 커피빈이며, Sour는 발효된 노르스 름한 커피빈으로 분류하였다.

\section{커피 로스팅 및 추출액 제조}

커피빈의 로스팅은 로스터기(Sample roaster Type PRG $1 \mathrm{Z}$, Probat Co., Ingolstadt, Germany)를 이용하였다. 본 실험 에서는 로스팅 강도를 medium roast로 설정하였으며, 이 강도는 SCAA Agtron Roast Color Classification \#55 disk 기준에 따르면 원두가 첫번째 팽창이 있은 후부터 두번째 팽창을 하기 전까지의 단계를 의미한다. 예비실험을 통해 이 단계에 부합하는 온도 및 시간은 $180^{\circ} \mathrm{C}$ 에서 9분이었으므 로 이것을 로스팅 조건으로 하였다. 로스팅 후 즉시 air cooler로 원두가 실온으로 식을 때까지 냉각 후 포장지에 담아 포장 후 암소에 보관하며 실험에 사용하였다. 커피빈 분말은 분쇄기(NSG-1002SS, Hanil Inc., Seoul, Korea)를 사 용하여 분쇄 후 $20 \mathrm{mesh}$ 체에 걸렀으며. 추출액은 $\mathrm{Kim}(19)$ 의 추출액 제조 조건을 변형하여 생두와 원두 커피빈 분말 $8.25 \mathrm{~g}$ 에 $92^{\circ} \mathrm{C}$ 의 3 차 증류수 $150 \mathrm{~mL}$ 을 가하여 4 분 동안 추출 후 여과지(No 2, Advantec, Tokyo, Japan)로 여과한 후, 이화학적 품질특성 및 항산화 활성 및 기능성 성분 분석 에 사용하였다.

추출액의 $\mathrm{pH}$, 적정산도, 가용성 고형분 함량, 색도

$\mathrm{pH}$ 는 $\mathrm{pH}$ meter(pH 510, Oakion, Singapore)을 이용하여 측정하였으며, 적정 산도는 $\mathrm{AOAC}$ 방법(20)에 따라 $0.1 \mathrm{~N}$ $\mathrm{NaOH}$ 로 적정하여 citric acid 함량으로 나타내었다. 가용성 고형분 함량은 굴절 당도계(Master-a, Atago, Tokyo, Japan) 를 이용하여 측정하였으며, 색도는 표준 백색판 $(\mathrm{L}=97.79$, $\mathrm{a}=-0.38, \mathrm{~b}=2.05)$ 으로 보정된 colorimeter(CR-400, Konica Minolta Co., Osaka, Japan)를 사용하였다.

\section{항산화 활성 및 페놀화합물}

1,1-diphenyl-2-picrylhydral(DPPH) 라디칼 소거능 측정 은 Blois의 방법(21)을 변용하여 측정하였다. 추출액을 40배 희석한 것을 시료용액으로 사용하였으며, $0.4 \mathrm{mM} \mathrm{DPPH}$ 용액을 흡광도 값이 0.95 0.99가 되도록 ethanol로 보정한 후 시료 용액 $0.2 \mathrm{~mL}$ 과 반응시킨 후 10 초 동안 진탕하고 암소에 10 분간 방치한 뒤 $517 \mathrm{~nm}$ 에서 흡광도를 측정하였 다. 라디칼 소거능은 다음의 식을 이용하였다.

\section{DPPH radical scavenging actiity $(\%)=$}

$$
\left(1-\frac{\text { Absorbance of sample }}{\text { Absorbance of blank }}\right) \times 100
$$

FRAP 활성은 Benzie 등의 방법(22)을 변용하여 측정하 였다. 반응용액은 acetate buffer( $\mathrm{pH} 3.6,300 \mathrm{mM}), 10 \mathrm{mM}$ TPTZ[2,4,6-tris (2-pyridyl-s-triazine)], $20 \mathrm{mM} \mathrm{FeCl} \cdot 6 \mathrm{H}_{2} \mathrm{O}$ 를 $10: 1: 1$ 비율로 혼합하여 $37^{\circ} \mathrm{C}$ 를 유지하면서, 추출액을 20 배 희석한 시료 $25 \mu \mathrm{L}$ 에 반응용액 $175 \mu \mathrm{L}$ 를 혼합한 뒤 암실에 서 30 분간 방치한 후, $590 \mathrm{~nm}$ 에서 흡광도를 측정하여 trolox equivalent(TE) $\mathrm{mM}$ 로 나타내었다. 총 페놀성 화합물은 Folin-Ciocalteu법(23)을 응용하여 정량하였다. 추출액을 120 배 희석한 것을 시료용액으로 하였으며, 시료용액 $1 \mathrm{~mL}$ 을 Folin-Ciocalteu reagent $1 \mathrm{~mL}$ 와 혼합하여 15 분간 방치한 후 $10 \% \mathrm{Na}_{2} \mathrm{CO}_{3} 1 \mathrm{~mL}$ 을 가하여 60 분 동안 반응시켜 760 $\mathrm{nm}$ 에서 흡광도를 측정하였으며, gallic acid를 표준물질로 하여 총 페놀성 화합물의 함량을 gallic acid equivalent (GAE) $\mathrm{mg} \%$ 로 나타내었다. 
Trigonelline, caffeine, chlorogenic acid 함량

Trigonelline, caffeine, chlorogenic acid 함량을 분석하기 위하여 커피빈 추출액 시료를 $0.45 \mu \mathrm{m}$ membrane filter로 여과하였으며, HPLC로 분석하였다. Trigonelline, caffeine, chlorogenic acid를 동시에 분석할 수 있는 Bradbury 등의 방법(24)에 준하여 측정하였으며. 분석조건은 Table 1과 같 다.

Table 1. HPLC conditions for analysis in trigonelline, caffeine and chlorogenic acid of coffee extracts

\begin{tabular}{cc}
\hline Items & Operating conditions \\
\hline Instrument & Shimadzu Prominence \\
Column & $\mathrm{C}_{18}(4.6 \mathrm{~mm} \times 150 \mathrm{~mm}, 5 \mu \mathrm{m})$ \\
Column temp. & $40^{\circ} \mathrm{C}$ \\
Mobile phase & $10 \mathrm{mM} \mathrm{HCl}: \mathrm{MeOH}=90: 10$ \\
Injection volume & $10 \mu \mathrm{L}$ \\
Flow rate & $1.0 \mathrm{~mL} / \mathrm{min}$ \\
Detector & Diode Array detector \\
\hline
\end{tabular}

\section{통계처리}

모든 실험 결과는 3회 반복하여 실시하였고 그 결과 값을 평균과 표준편차로 표시하고(mean $\pm \mathrm{SD}), \mathrm{SAS}$ program(9.4, SAS Institute, Inc., Cary, NC, USA)을 이용하여 분산분석과 Duncan's multiple range test $(\mathrm{p}<0.05)$ 를 실시하였다.

\section{결과 및 고찰}

\section{추출액의 이화학적 특성}

정상두와 결점두의 로스팅 전후에 얻은 추출액의 $\mathrm{pH}$, 적정산도, 가용성 고형분 함량, 색도를 분석한 결과는 Table 2 에 나타내었다. 생두 추출액의 $\mathrm{pH}$ 는 원두 추출액보다 높 았으며 적정산도는 Sour bean의 생두 추출물이 가장 높았는 데 이는 품질이 낮은 커피는 발효된 생두에 의해 산도가 높다고 한 Mazzafera(25)의 결과와 유사하였다. 가용성 고 형분 함량은 생두 추출물이 원두 추출물보다 다소 높은 경향을 보였으며 Immature의 생두 추출물이 $2.30{ }^{\circ} \mathrm{Brix}$ 로 가장 높았으며, Broken의 원두 추출물이 $1.17^{\circ} \mathrm{Brix}$ 로 가장 낮았다. $\mathrm{L}^{*}$ value는 로스팅 공정 후 감소하는 경향을 보였으 며, 정상두의 생두 추출물이 62.97로 가장 높았다. 이는 로 스팅에 따라 명도가 감소하는 Lee 등(29)의 결과와 일치하 였다. $\mathrm{a}^{*}$ value와 $\mathrm{b}^{*}$ value는 로스팅 과정을 거친 후 증가하였 다. $\mathrm{a}^{*}$ value 값은 정상두의 원두 추출물이 9.83 으로 가장 높았으며 Fungus의 생두 추출물이 -2.50 으로 가장 낮은 수 치를 나타냈다. $b^{*}$ value 값은 Broken의 원두 추출물이 23.21 으로 가장 높았고, 정상두의 생두 추출물이 2.49 으로 가장 낮은 것으로 나타냈다.
Table 2. The physicochemical qualities of coffee extracts

\begin{tabular}{|c|c|c|c|c|c|c|c|}
\hline \multicolumn{2}{|c|}{ Samples ${ }^{1)}$} & $\mathrm{pH}$ & $\begin{array}{c}\text { Titratable } \\
\text { acidity (\%) }\end{array}$ & $\begin{array}{c}\text { Soluble solid } \\
\text { contents } \\
\left({ }^{\circ} \text { Brix }\right)\end{array}$ & $\mathrm{L}^{*}$ value & $a^{*}$ value & $\mathrm{b}^{*}$ value \\
\hline \multirow{5}{*}{$\mathrm{G}$} & $\mathrm{N}$ & $6.31 \pm 0.13^{22)}$ & $0.96 \pm 0.03^{c}$ & $2.00 \pm 0.00^{c}$ & $62.97 \pm 0.08^{\mathrm{a}}$ & $-0.69 \pm 0.02^{\mathrm{a}}$ & $2.49 \pm 0.02^{\mathrm{e}}$ \\
\hline & I & $6.00 \pm 0.07^{\mathrm{b}}$ & $1.44 \pm 0.06^{\mathrm{a}}$ & $2.30 \pm 0.00^{\mathrm{a}}$ & $59.25 \pm 0.02^{\mathrm{e}}$ & $-2.11 \pm 0.02^{\mathrm{d}}$ & $12.63 \pm 0.05^{\mathrm{a}}$ \\
\hline & $\mathrm{F}$ & $5.97 \pm 0.03^{\mathrm{b}}$ & $1.13 \pm 0.04^{b}$ & $2.00 \pm 0.00^{c}$ & $61.36 \pm 0.03^{\mathrm{d}}$ & $-2.50 \pm 0.02^{\mathrm{e}}$ & $9.35 \pm 0.06^{b}$ \\
\hline & B & $5.82 \pm 0.08^{c}$ & $1.24 \pm 0.09^{b}$ & $2.00 \pm 0.00^{c}$ & $62.60 \pm 0.11^{b}$ & $-0.79 \pm 0.02^{b}$ & $3.25 \pm 0.03^{\mathrm{d}}$ \\
\hline & S & $5.73 \pm 0.06^{\mathrm{c}}$ & $1.48 \pm 0.10^{\mathrm{a}}$ & $2.10 \pm 0.00^{b}$ & $61.69 \pm 0.27^{\mathrm{c}}$ & $-1.16 \pm 0.03^{c}$ & $6.27 \pm 0.05^{\circ}$ \\
\hline \multirow{5}{*}{$\mathrm{R}$} & $\mathrm{N}$ & $5.21 \pm 0.06^{b}$ & $1.32 \pm 0.09^{\mathrm{ab}}$ & $1.90 \pm 0.00^{b}$ & $43.57 \pm 0.02^{c}$ & $9.83 \pm 0.03^{\mathrm{a}}$ & $17.10 \pm 0.09^{\circ}$ \\
\hline & I & $5.24 \pm 0.05^{b}$ & $1.36 \pm 0.06^{\mathrm{a}}$ & $1.87 \pm 0.06^{b}$ & $43.43 \pm 0.07^{c}$ & $9.40 \pm 0.07^{b}$ & $16.78 \pm 0.08^{8}$ \\
\hline & $\mathrm{F}$ & $5.40 \pm 0.07^{\mathrm{a}}$ & $1.28 \pm 0.02^{\mathrm{ab}}$ & $1.90 \pm 0.00^{\mathrm{b}}$ & $44.51 \pm 0.18^{b}$ & $9.05 \pm 0.04^{c}$ & $18.12 \pm 0.20^{b}$ \\
\hline & B & $5.43 \pm 0.08^{\mathrm{a}}$ & $1.11 \pm 0.01^{c}$ & $1.17 \pm 0.06^{\mathrm{c}}$ & $49.35 \pm 0.01^{\mathrm{a}}$ & $6.34 \pm 0.02^{d}$ & $23.21 \pm 0.02^{\mathrm{a}}$ \\
\hline & $S$ & $5.31 \pm 0.08^{\mathrm{ab}}$ & $1.21 \pm 0.09^{b c}$ & $2.00 \pm 0.00^{\mathrm{a}}$ & $40.05 \pm 0.07^{\mathrm{d}}$ & $9.76 \pm 0.13^{\mathrm{a}}$ & $11.37 \pm 0.22^{\mathrm{e}}$ \\
\hline
\end{tabular}

${ }^{1)} \mathrm{G}$, green bean; R, roasted bean; $\mathrm{N}$, non-defective; I, immature; F, fungus; B, broken; $S$, sour.

${ }^{2}$ Means \pm SD ( $n=3$ ) with different letters are significantly different at $5 \%$ level

\section{항산화 활성 및 페놀화합물}

정상두와 결점두의 로스팅 전후에 얻은 추출액의 DPPH 라디칼 소거능 결과는 Fig. 1에 제시하였다. 라디칼 소거능 에 사용된 DPPH는 안정한 자유라디칼로 $517 \mathrm{~nm}$ 부근에서

(A)
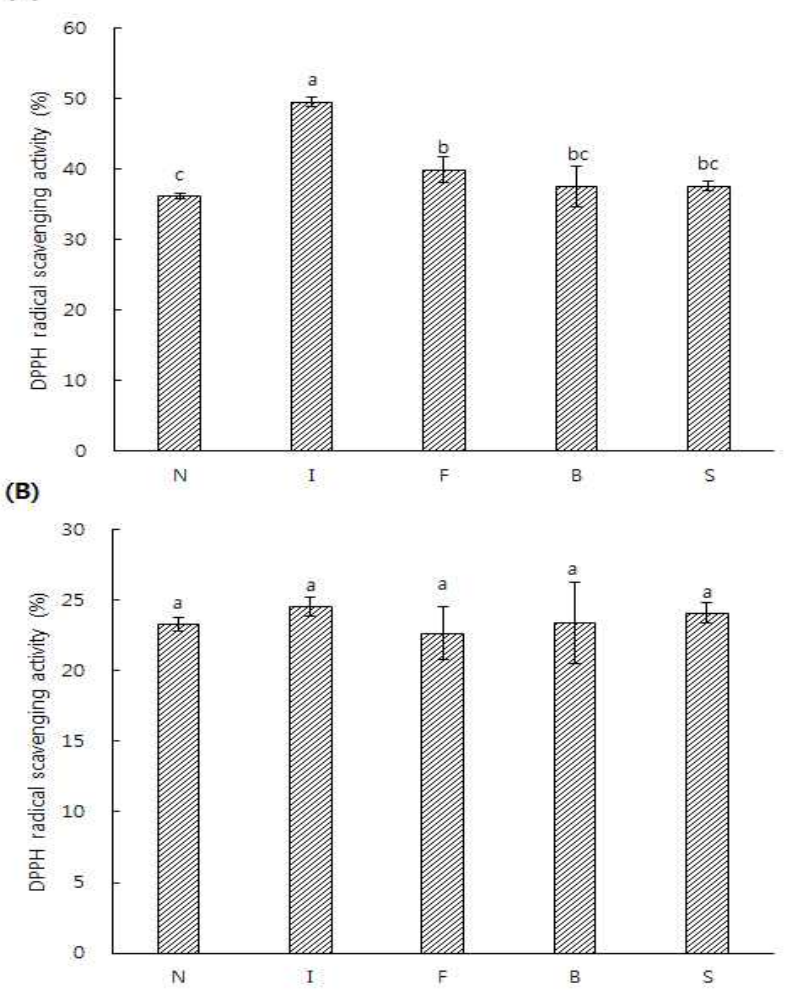

Fig. 1. DPPH radical scavenging activity of coffee extracts.

(A), green bean extract; (B), roasted bean extract.

$\mathrm{N}$, non-defective; I, immature; $\mathrm{F}$, fungus; $\mathrm{B}$, broken; S, sour.

Means \pm SD ( $n=3)$ with different letters are significantly different at $5 \%$ level. 
최대 흡광도를 나타내며 전자 또는 수소를 받으면 $517 \mathrm{~nm}$ 부근에서 흡광도가 감소하며(26), 방향족 아민류 및 방향족 화합물 등에 의해 환원되어 짙은 자색이 탈색되는 것으로 항산화능을 측정하는 방법이다(27). 추출물의 라디칼 소거 능은 로스팅을 한 후 감소하는 경향을 보였는데 이는 로스 팅 후 라디칼 소거능이 감소한다는 Cheong 등의 결과(28)와 일치하였다. 또한 생두 추출물에서는 정상두보다 결점두의 라디칼 소거능이 높았으며 특히 Immature의 생두 추출물의 $\mathrm{DPPH}$ 라디칼 소거능이 $49.54 \%$ 로 가장 높게 나타났으며, 정상두가 $36.17 \%$ 로 가장 낮은 수치를 나타냈다. 로스팅을 한 후 추출물간에는 유의적인 차이를 보이지 않았으며 Fungus의 원두 추출물이 $22.66 \%$ 로 가장 낮게 나타났다. 정상두와 결점두의 로스팅 전후에 얻은 추출액의 FRAP 활성을 분석한 결과는 Fig. 2에 제시하였다. FRAP assay는 colored ferrous tripyridyl triazine complex에 의해 ferric ion 이 ferrous로 전환되어지는 과정을 분석함으로써 시료 내의 총 항산화력을 측정하는 방법이다(29). Broken을 제외한 생두 추출물은 원두 추출물보다 FRAP 활성이 높았으며, 이는 로스팅 후 FRAP 활성이 감소한 Cheng 등(28)의 결과 와 일치하였다. 생두 추출물에서는 모든 결점두 추출물이 정상두 추출물에 비해 높은 활성을 나타내었다. 또한 Immature의 생두 추출물이 $21.80 \mathrm{mM} \mathrm{TE}$ 로 활성이 가장
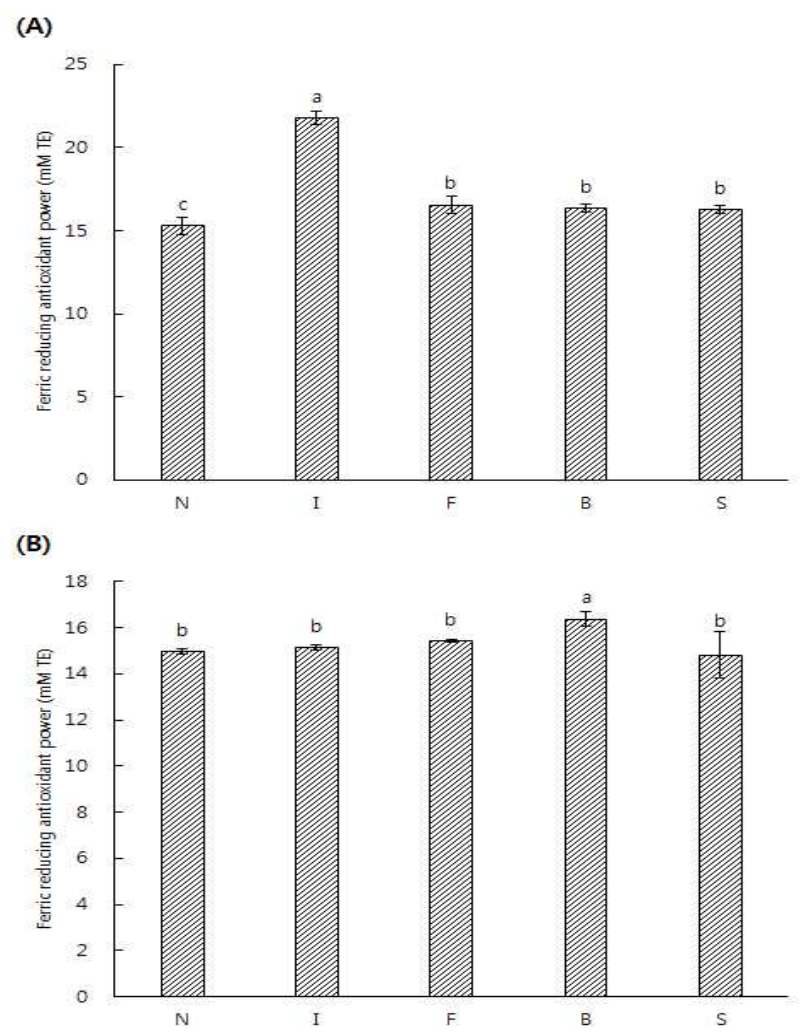

Fig. 2. Ferric reducing antioxidant power of coffee extracts.

(A), green bean extract; (B), roasted bean extract.

$\mathrm{N}$, non-defective; I, immature; F, fungus; $\mathrm{B}$, broken; S, sour

Means \pm SD $(n=3)$ with different letters are significantly different at $5 \%$ level.
높았으며, Sour의 원두 추출물이 $14.81 \mathrm{mM} \mathrm{TE}$ 로 가장 낮은 활성을 나타내었다. 식품에 존재하는 폴리페놀 물질은 산 화환원반응을 기본으로 항산화, 항암 및 항균효과 등의 생 리활성을 나타낸다고 보고되고 있다 $(30,31)$. 정상두와 결점 두의 로스팅 전후에 얻은 추출액의 총 페놀성 화합물 함량 측정 결과는 Fig. 3과 같다. 총 페놀성 화합물 함량은 Immature의 생두 추출물이 $256.25 \mathrm{mg} \% \mathrm{GAE}$ 로 가장 높았 으며 이는 페놀성 화합물의 함량이 커피의 항산화력과 밀접 한 관련을 보인다고 보고한 Lee 등(32)의 결과와 유사하였 다. 생두 추출물은 원두 추출물에 비해 페놀 화합물 함량이 높았으며 원두 추출물간에는 유의적인 차이를 보이지 않았 으며 Immature의 원두 추출물이 $161.91 \mathrm{mg} \% \mathrm{GAE}$ 로 가장 낮게 나타났다.
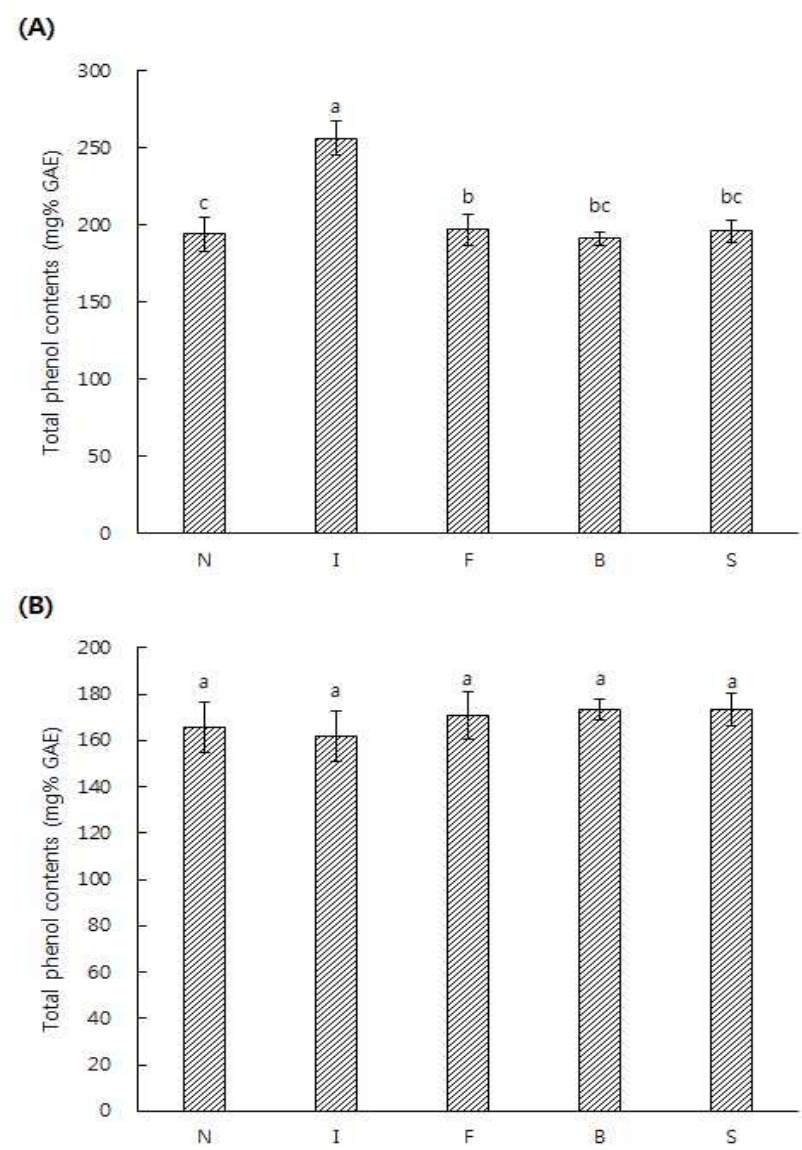

Fig. 3. Total phenol contents of coffee extracts.

(A), green bean extract; (B), roasted bean extract.

$\mathrm{N}$, non-defective; I, immature; F, fungus; $\mathrm{B}$, broken; $\mathrm{S}$, sour. Means \pm SD $(n=3)$ with different letters are significantly different at $5 \%$ level.

Trigonelline, caffeine, chlorogenic acid 함량 커피의 주요 화학 성분인 trigonelline, caffeine, chlorogenic acid의 로스팅 전 후의 함량을 측정한 결과는 Table 3 과 같다. Trigonelline은 퓨린-알칼로이드로서 매우 약한 쓴맛 을 지니고 있으나 로스팅 공정 중 급격히 분해되어 주요 
휘발성 성분들을 생성하며, 이 성분들이 커피품질에 많은 영향을 미치므로 중요한 화학성분으로서 역할을 한다고 알려져 있다 $(33,34)$. Trigonelline 함량은 Immature의 생두 추출물에서 $895.20 \mathrm{mg} / \mathrm{L}$ 로 가장 높은 수치를 나타냈으며 로스팅 공정 후 전반적으로 함량이 낮아졌으며 Sour의 원두 추출물이 $330.81 \mathrm{mg} / \mathrm{L}$ 로 가장 낮았다. Caffeine은 퓨린 염기 의 일종으로 평활근의 이완작용, 이뇨작용 중추신경 자극, 혈관 확장 뿐 아니라 최근 라디칼 소거 및 항산화 작용 등의 기능도 보고되는 기능성 성분이다(35-37). Caffeine의 함량은 Immature의 생두 추출물에서 $825.85 \mathrm{mg} / \mathrm{L}$ 로 가장 높았으며 Broken의 원두 추출물이 $431.75 \mathrm{mg} / \mathrm{L}$ 로 가장 낮 은 수치를 나타냈다. 로스팅 공정 후 정상두와 Fungus, Sour 는 caffeine 함량이 증가하였는데 이는 Kim 등(16)의 결과와 유사하였다. Chlorogenic acid는 커피 속에 다량 함유되어 있는 폴리페놀 성분의 일종으로서 커피의 착색 및 쓴맛의 원인물질로 알려져 있다(38). 또한 생체 내에서 항산화작용 은 물론 항균활성 및 항암성 물질로 작용하여 기능성 소재 의 성분으로 보고되어 왔다 $(8,35)$. Chlorogenic acid 함량은 Immature의 생두 추출물에서 $3,836.94 \mathrm{mg} / \mathrm{L}$ 로 가장 높았으 며 Sour의 원두 추출물이 $392.44 \mathrm{mg} / \mathrm{L}$ 로 가장 낮은 수치를 나타내었다. 모든 샘플에서 로스팅 후 함량이 급격하게 감 소하였는데 이는 Franca 등(39)과 Kim 등(40)의 결과와 유 사하였다. 세 가지 기능성분 함량 모두에서 Immature의 생 두 추출물에서 가장 높은 함량을 나타내었는데 이런 영향으 로 Immature의 생두 추출물이 가장 높은 항산화능을 보이는 것으로 사료된다.

Table 3. Contents of trigonelline, caffeine and chlorogenic acid of coffee extracts

\begin{tabular}{ccccc}
\hline \multicolumn{2}{c}{ Samples ${ }^{\mathrm{l}}$} & Trigonelline & Caffeine & Chlorogenic acid \\
\hline & N & $579.65 \pm 2.08^{\mathrm{e} 2)}$ & $557.27 \pm 4.78^{\mathrm{d}}$ & $3080.07 \pm 23.85^{\mathrm{b}}$ \\
& I & $895.20 \pm 2.62^{\mathrm{a}}$ & $825.85 \pm 8.52^{\mathrm{a}}$ & $3836.94 \pm 110.99^{\mathrm{a}}$ \\
G & F & $635.27 \pm 5.72^{\mathrm{d}}$ & $640.04 \pm 9.47^{\mathrm{b}}$ & $2634.53 \pm 117.00^{\mathrm{c}}$ \\
& B & $641.86 \pm 0.68^{\mathrm{c}}$ & $586.18 \pm 1.54^{\mathrm{c}}$ & $3152.57 \pm 60.13^{\mathrm{b}}$ \\
& S & $687.22 \pm 0.55^{\mathrm{b}}$ & $645.72 \pm 8.71^{\mathrm{b}}$ & $2996.94 \pm 124.45^{\mathrm{b}}$ \\
\hline & N & $464.48 \pm 2.56^{\mathrm{a}}$ & $606.29 \pm 6.66^{\mathrm{c}}$ & $629.26 \pm 37.99^{\mathrm{a}}$ \\
& R & $402.40 \pm 1.65^{\mathrm{c}}$ & $645.26 \pm 3.21^{\mathrm{b}}$ & $544.60 \pm 28.20^{\mathrm{bc}}$ \\
& F & $447.35 \pm 5.62^{\mathrm{b}}$ & $642.98 \pm 1.22^{\mathrm{b}}$ & $603.23 \pm 41.50^{\mathrm{ab}}$ \\
& B & $341.51 \pm 0.64^{\mathrm{e}}$ & $431.75 \pm 1.45^{\mathrm{d}}$ & $517.09 \pm 29.33^{\mathrm{c}}$ \\
& S & $330.81 \pm 5.27^{\mathrm{d}}$ & $670.48 \pm 0.94^{\mathrm{a}}$ & $392.44 \pm 29.34^{\mathrm{d}}$ \\
\hline
\end{tabular}
${ }^{1)} \mathrm{G}$, green bean; R, roasted bean; N, non-defective; I, immature; F, fungus; B, broken;
S, sour.

${ }^{2)}$ Means \pm SD ( $n=3$ ) with different letters are significantly different at $5 \%$ level.

\section{요 약}

커피의 풍미와 기호에 부정적인 영향을 미친다고 알려진 결점두의 활용가능성을 알아보고자 생두와 원두상태의 정 상두와 결점두의 이화학적 특성을 분석하였다. 추출액의 $\mathrm{pH}$ 와 가용성 고형분 함량은 로스팅 공정을 거친 후 감소하 는 경향을 보였으며 색도는 $\mathrm{L}^{*}$ value는 감소하고 $\mathrm{a}^{*}$ value와 $\mathrm{b}^{*}$ value는 증가하였다. DPPH radical 소거능은 로스팅 공정 을 거친 후 감소하였으며 생두 추출물에서 결점두의 radical 소거능이 정상두보다 높았으며 Immature의 생두 추출물이 $49.54 \%$ 로 가장 높은 소거능을 나타냈다. 로스팅을 한 후 DPPH radical 소거능 원두 추출물간에는 유의적인 차이를 보이지 않았다. FRAP 활성 또한 생두 추출물이 15.28 21.80 $\mathrm{mM} \mathrm{TE}$ 로 $14.81 \sim 16.38 \mathrm{mM} \mathrm{TE}$ 의 활성을 나타낸 원두 추출물보다 높았으며 Sour의 원두 추출물을 제외하고 정상 두에 비해 결점두의 FRAP 활성이 높게 나타났다. 총 페놀 성 화합물 함량은 생두 추출물이 191.06 256.25 mg\% GAE 의 범위로 $161.91 ~ 173.44 \mathrm{mg} \% \mathrm{GAE}$ 의 범위를 나타낸 원두 추출물보다 높은 함량을 보였으며 Immature의 생두 추출물 이 $256.25 \mathrm{mg} \%$ 로 가장 높게 나타났다. Trigonelline, caffeine, chlorogenic acid 함량은 Immature의 생두 추출물이 각각 $895.20 \mathrm{mg} / \mathrm{L}, 825.85 \mathrm{mg} / \mathrm{L}, 3,836.94 \mathrm{mg} / \mathrm{L}$ 로 가장 높은 수치를 나타내었고, 로스팅 공정을 거친 후 감소하였으며 특히 chlorogenic acid의 함량은 급격히 감소하였다. 이상의 실험결과로 미루어 보아 결점두의 항산화능과 기능성을 활용할 수 있을 것으로 판단되며 특히 활용할 시 생두의 형태가 더 적합하다고 판단된다.

\section{References}

1. Shin WR, Choi YM, Yoon HH (2011) The sensory characteristics of espresso according to grinding grades of coffee beans. Korean J Food Cookery Sci, 27, 85-99

2. Clarke R (1985) Packaging of Roast and Instant Coffee. Springer Publishing, Houten, Netherlands, p 201-219

3. Grosch W (1995) Instrumental and sensory analysis of coffee volatiles. Proceedings of the 16th ASIC colloquium, 16, 147-156

4. Jang SM, Hur GT, Lee JK, Kim YH (2006) Coffee Science. Kwangmoonkag, Seoul, Korea, p 222

5. Dorea J, da Costa T (2005) Is coffee a functional food?. Brit J Nutr, 93, 773-782

6. Karakaya S, El SN, Tas AA (2001) Antioxidant activity of some foods containing phenolic compounds. Int J Food Sci Nutr, 52, 501-508

7. Morton C, Klatsky AL, Udaltsova N (2004) Smoking, 
coffee, and pancreatitis. Am J Gastroenterol, 99, 731-738

8. Salazar-Martinez E, Willett WC, Ascherio A, Manson JE, Leitzmann MF, Stampfer MJ, Hu FB (2004) Coffee consumption and risk for type 2 diabetes mellitus. Ann Intern Med, 140, 1-8

9. Higdon JV, Frei B (2006) Coffee and health: review of recent human research. Crit Rev Food Sci Nutr, 46, 101-123

10. Farah A, Monteiro MC, Calado V, Franca AS, Trugo LC (2006) Correlation between cup quality and chemical attributes of Brazilian coffee. Food Chem 98, 373-380

11. SCAA (2011) SCAA Arabica green coffee defect handbook. SCAA Publishing, Santa Ana, CA, USA, p 1-31

12. Franca AS, Mendonca JCF, Oliveira SD (2005) Composition of green and roasted coffees of different cup qualities. LWT-Food Sci Technol, 38, 709-715

13. Smith AW, Clart RJ, Macrea R (1985) Coffee Chemistry. Elsevier Applied Science, London and New York, p 1-41

14. Bee S, Brando CHJ, Brumen G, Carvalhaes N, Kolling-Speer I, Speer K (2005) Espresso coffee, the science of quality. In: The Raw Bean, Illy A, R Viani (Editor), Elsevier Academic Press, Italy, p 87-178

15. ISO (2004) Green coffee-defect reference chart. ISO 10470/2004. Prepared by Technical Committee ISO/TC 34, Agricultural food products. Switzerland

16. Baik HJ (1986) Headspace gas chromatographic analysis and sensory evaluation of various domestic and foreign-made commercial roasted and ground coffee. MS Thesis Hanyang University, Korea

17. Kim HK, Hwang SY, Yoon SB, Chun DS, Kong, SK, Kang KO (2007) A study of the characteristics of different coffee beans by roasting and extracting condition. Korean J Food Sci Nutr, 20, 14-19

18. Eun JB, Jo MY, Im JS (2014) Physicochemical characteristics of coffee extracts using different extraction methods. Korean J Food Sci Technol, 46, 723-728

19. Kim YS, Lee SH (2013) Coffee extraction temperature, extraction time and drinking temperature on the difference in coffee taste and preference study. J Dig, 11, 711-718

20. AOAC (2000) Official Methods of Analysis. 17th ed, Association of Official Analytical Chemists, Washington DC, USA

21. Blois MS (1958) Antioxidant determination by the use of a stable free radical. Nature, 181, 1199-1200

22. Benzie IFF, Strain JJ (1996) The ferric reducing ability of plasma (FRAR) as a measure of "Antioxidant power": the FRAP assay. Anal Biochem, 239, 70-76

23. Benvenuti S, Pellati F, Melegari M, Bertelli D (2004) Polyphenols, anthocyanins, ascorbic acid, and radical scavenging activity of Rubus, Ribes, and Aronia. J Food Sci, 69, 164-169

24. Bradbury A, Weers M (1995) Non-volatile compounds analysis in coffee. Kraft Eur Anal Method, 5-17

25. Mazzafera P (1999) Chemical composition of defective coffee beans. Food Chem, 64, 547-554

26. Shin YS, Lee JE, Yeon IK, Do HW, Cheung JD, Kang CK, Choi SY, Youn SJ, Cho JG, Kwoen DJ (2008) Antioxidant and antimicrobial effects of extract with water and ethanol of oriental melon (Cucumis melo L.var makuwa Makino). J Appl Biol Chem, 51, 194-199

27. Ancerewicz J, Migliavacca E, Carrupt PA, Testa B, Bree F, Zini R, Tillement JP, Labidalle S, Guyot D, Chauvet-Monges AM, Crevat A, Le Ridant A (1998) Structure - property relationships of trimetazidine derivatives and model compounds as potential antioxidants. Free Radic Biol Med, 25, 113-120

28. Cheong MQ, Tong KH, Ong JJM, Liu SQ, Curran P, $\mathrm{Yu} B$ (2013) Volatile composition and antioxidant capacity of Arabica coffee. Food Res Int, 51, 388-396

29. Liu L, Sun Y, Laura T, Liang X, Ye H, Zeng X (2009) Determination of polyphenolic content and antioxidant activity of kudingcha made from Ilex kudingcha C.J. Tseng. Food Chem, 112, 35-41

30. Kuroda Y, Hara Y (1999) Antimutagenic and anticarcinogenic activity of tea polyphenols. Mutat Res, 436, 69-97

31. Pyo YH, Lee TC, Logendra L, Rosen RT (2004) Antioxidant activity and phenolic compounds of Swiss chard (Beta vulgaris subspecies cycla) extracts. Food Chem, 85, 19-26

32. Lee JW, Shin HS (1996) Physicochemical properties of antioxidant fractions extracted from freeze-dried coffee by various solvents. Korean J Food Sci Technol, 28, 109-116

33. Viani R, Horman I (1974) Thermal behavior of trigonelline. J Food Sci, 39, 1216-1217

34. Viani R, Horman I (1975) Determination of trigonelline in coffee. Proc Coll ASIC, Montpellier, France, p 275-278

35. Lean MEJ, Crozier A (2012) Coffee, caffeine and health: What's in your cup?. Maturitas, 72, 171-172

36. Niseteo T, Komas D, Belscak-Cvitanovic A, Horzic D, Budec M (2012) Bioactive composition and antioxidant potential of different commonly consumed coffee brews 
affected by their preparation technique and milk addition. Food Chem, 134, 1870-1877

37. Crozier TWM, Stalmach A, Lean MEJ, Crozier A (2012) Espresso coffees, caffeine and chlorogenic acid intake: potential health implications. Food Funct, 3, 30-33

38. Link A, Balaguer F, Goel A (2010) Cancer chemoprevention by dietary polyphenols: promising role for epigenetics. Biochem Pharmacol, 80, 1771-1792
39. Franca AS, Oliveira LS, Mendonca JCF, Silva XA (2005) Physical and chemical attributes of crude and roasted coffee beans. Food Chem, 90, 89-94

40. Kim KJ, Park SK (2006) Changes in major chemical constituents of green coffee beans during the roasting. Korean J Food Sci Technol, 38, 153-158 